\title{
GREEN BUILDING POLICY FORMULATION IN THE MUNICIPALITY OF BANDUNG INDONESIA
}

\author{
Engkus \\ Department of Public Administration, Faculty of Social and Political Sciences, \\ State Islamic University Sunan Gunung Djati Bandung. \\ E-mail: engkus@uinsgd.ac.id
}

\begin{abstract}
Land use that is not based on spatial planning based on green building concepts. This study aims to find out how the formulation of Bandung Mayor Regulation Number 1023 of 2016 concerning Green Buildings tested the system model(David, 1981). This study uses a qualitative approach with actual problems that occur in life (Engkus E, 2017). Policy formulation uses 5 (five) dimensions, namely input, process, output, environment, feedback. The results show that there are problems: a more complex green building policy, imposed on all buildings including housing; lack of community knowledge and understanding of the concept of green buildings, so that the community participates less; limited green building policy dissemination.
\end{abstract}

Key words: policy formulation; bandung mayor regulation; green building; community understanding.

\section{FORMULASI KEBIJAKAN BANGUNAN HIJAU DI KOTA BANDUNG INDONESIA}

\begin{abstract}
ABSTRAK. Penggunaan lahan yang tidak didasarkan pada perencanaan tata ruang yang berbasis konsep bangunan hijau. Penelitian ini bertujuan untuk mengetahui bagaimana rumusan kebijakan Peraturan Walikota Bandung Nomor 1023 Tahun 2016 tentang Bangunan Hijau yang diuji model sistem (David, 1981). Penelitian ini menggunakan pendekatan kualitatif dengan masalah aktual yang terjadi dalam kehidupan (Engkus E, 2017). Perumusan kebijakan menggunakan 5 (lima) dimensi, yaitu input, proses, output, lingkungan, umpan balik. Hasil menunjukkan bahwa ada masalah: kebijakan bangunan hijau yang lebih kompleks, dikenakan pada semua bangunan termasuk perumahan; kurangnya pengetahuan masyarakat dan pemahaman tentang konsep bangunan hijau, sehingga masyarakat kurang berpartisipasi; penyebaran kebijakan bangunan hijau terbatas.
\end{abstract}

Kata kunci: perumusan kebijakan; peraturan walikota bandung; bangunan hijau; pemahaman komunitas

\section{INTRODUCTION}

Population growth in the last two centuries shows an exponential, very rapid and uncontrolled especially at the end of this century, giving rise to various kinds of problems, both problems for humans themselves and for the earth as their place of residence. Humans to make ends meet, that is by utilizing natural resources on earth. Uncontrolled development and lifestyles have increased the need for electricity, water and other resources, especially in urban areas.

In Scientific American Magazine on October 27, 2011 published a report that said that the larger population also needed more resources, starting from water, food, minerals, to energy and the availability of land for agriculture (Wilmoth, 2011). Therefore electricity production also increased tremendously while releasing $\mathrm{CO} 2$ which is the biggest contribution as a greenhouse gas. Over the past hundreds of thousands of years the concentration of $\mathrm{CO} 2$ in the atmosphere was almost constant at $230 \mathrm{ppm}$, but since the industrial revolution in the 18th century, it has risen sharply and is currently at the level of 400 ppm in just 150 years. This resulted in an increase in the earth's global temperature by $10 \mathrm{C}$. If the pattern of energy consumption is still as it is now, then by 2050 , global temperatures will increase to $2 \mathrm{oC}$, and that will cause polar ice to melt, causing sea level rise that will sink many areas such as Manhattan in New York, Shanghai, and Mekhong river delta.

In addition, such an increase in electricity consumption can lead to petroleum scarcity. Nearly half of electricity in Indonesia comes from petroleum, and only $5 \%$ of renewable energy. Indonesia, which was once famous as a petroleum-producing country, has now become a "net importer of country oil" and has oil reserves for only 20 years, less than a generation.

Those are some of the problems caused by greed and human negligence. However, if humans can change their patterns of life then all fears of natural resource crises can be overcome. The whole world is now focused on finding solutions to various natural problems that arise. One solution is to apply the concept of green building.

This is one form of responsibility from professionals in the building industry in relation to the environmental impact it causes. Green building is a building that since planning, construction during construction and operation and maintenance during its utilization period uses natural resources to a minimum, uses the land wisely, reduces environmental impacts and creates air quality in a healthy and comfortable room. The green building concept will reduce energy consumption significantly through several passive design methods and active designs. Using the 
concept of green building does not need to sacrifice comfort and productivity due to energy savings. Green building is not only saving energy but also saving water, preserving natural resources, and improving air quality and good waste management. In anticipating the clean water crisis, the concept of reducing water use has been developed by producing sanitary ware that saves water, reuse water for various purposes at the same time (reuse), recycles recycled water, and utilizes rainwater that falls on the roof building (rain water harvesting). Indonesian Engineers Association,(Subijono E, 2016).

Recognition of a building as green building is obtained after being certified based on the appraisal device (rating tools). Green Building Council Indonesia (GBCI) developed an assessment device called Greenship. Other countries that have followed the movement of green buildings also have their own rating system, for example the United States has Leadership in Energy and Environmental Design (LEED), Singapore has a Green Mark, and Australia has a Green Star, a Green Building Council Indonesia(Recognition, 2018) the following in table 1.

Table 1. Green Building Value Device in Indonesia

\begin{tabular}{|c|c|c|}
\hline \multicolumn{2}{|r|}{ Greenship Type } & Greenship Category \\
\hline 1 & Greenship New Building & $\begin{array}{ll}1 \text { Appropriate Site } \\
\text { Development (ASD) }\end{array}$ \\
\hline 2 & $\begin{array}{l}\text { Greenship Existing } \\
\text { Building }\end{array}$ & $\begin{array}{l}2 \text { Energy Efficiency and } \\
\text { Conservation (EEC) }\end{array}$ \\
\hline 3 & Greenship Interior Space & 3 Water Conservation (WAC) \\
\hline 4 & Greenship Homes & $\begin{array}{l}4 \text { Material Resource and Cycle } \\
\text { (MRC) }\end{array}$ \\
\hline 5 & $\begin{array}{l}\text { Greenship } \\
\text { Neighbourhood }\end{array}$ & $\begin{array}{l}5 \text { Indoor Air Health and } \\
\text { Comfort (IHC) }\end{array}$ \\
\hline & & $\begin{array}{l}6 \text { Building and Environment } \\
\text { Management (BEM) }\end{array}$ \\
\hline
\end{tabular}

On 18 February 2015, the Central Government through the Ministry of Public Works and Housing established a green building policy based on Regulation Number 2 of 2015 concerning Green Buildings whose policy coverage included: (1) disseminating the Ministerial Regulation policy; (2) disseminating the Green Building Management Strategy Concept 2015-2019 focuses on strengthening local government institutions, (3) priorities are Metropolitan Cities, districts/ cities in the National Strategic Area, (4). The Central and Local Governments can be the initial motors for implementing the ministerial regulation, (5) collaborating with government strategic partners such as the Research Center and GBCI, (6) the Ministry of Public Works and Public Housing is the leading building construction sector. This policy is intended to ensure the realization of sustainable development in urban areas. This is in line with national commitments in 2011, to reduce Green House Gase (GHG) emissions voluntarily by $26 \%$ in 2020 from Business as Usual (BAU) conditions and reach $41 \%$ if assisted by international funding support, (Equipment Indonesia Magazine) This shows Indonesia's seriousness to participate in safeguarding the life of the world as a whole, which is a real action from the goal of the state that will interfere in efforts to control the world. The Municipality of Bandung is one of the national strategic areas, which is also the first city/ district in Indonesia to establish a green building policy, through the Mayor's Regulation Number 1023 concerning Green Building which was set on August 26, 2016. This policy is motivated by the density of Bandung Municipality with the increasing number of buildings, which is an improvement, but on the other hand there are also negative sides related to the environment and climate change. The Bandung Municipality Government has a target to reduce the Carbon Footprint (CO2). This regulation is led by the Office of Spatial Planning and Human Settlements, and facilitated by IFC (International Financial Corporation) which has concern for urban development throughout the world, which focuses on sustainable development especially environmentally friendly. This principle basically wants to realize environmentally friendly development, save energy, always put forward sustainable or sustainable aspects, (Mayor of Bandung Press Conference on Greetings and Expectations on the issuance of the Green Building). the following in table 2. But in the formulation of policies is still not optimal, because it is faced with several obstacles: (1) The Mayor of Bandung Regulations are still top down which is more manifesting the policies of the central government; Mayor Regulation Number 1023 of 2016 concerning Green Buildings is an embodiment of the Minister of Public Works Public Housing Regulation Number 2 of 2015 concerning Green Buildings which makes the duty of sectoral tasks of public works from the center to the regions, so that the policy formulation is based on internal manuscripts in the preparation of mayor regulations the city of Bandung with limited related institutions; (2) Community participation is still limited, and stakeholder involvement is still not optimal, both for citizens, local NGOs, other related agencies and regional institutions, and universities; in the preparation of policy formulations the mayor's regulations are usually technical in nature, with more immediate handling, so that the formulation rarely / does not involve the wider community. Program implementation is often less successful due to: low participation, the program is not well targeted because the information is less accurate, technology is not as needed, information and innovation (Banuwa \& I.S, 2018). 
ISSN 1411 - 0911 : eISSN: 2443-2660

(3) The level and capacity of regional head regulations, namely the regulations of the Mayor, are still limited, they cannot yet be more legally binding on the community as regional regulations. In accelerating the implementation of policies in technical and sectoral executors that are driven by community dynamics and the complexity of problems with the level of demand for handling urgent actions, require regulations that are formulated at the technical level, so that in addition to being more flexible these rules can be immediately used as an operational basis in implementation in the field. Therefore it is necessary to integrate development policies directed at controlling(Achdiat \& M, 2017). Furthermore, complete and clear understanding, direction, and instructions are needed to be able to interpret correctly (Suyatna U, 2019). Author based on these various considerations and descriptions, then use a theoretical basis based on the complexity of the object of research with a suitable theory, namely the theory of David Easton's system model.

Table 2. Number of Customers, Connected Power and Sold Energy State Electricity Company in Bandung Municipality, 2016

\begin{tabular}{cccc}
\hline Year & Customers & $\begin{array}{c}\text { Connected } \\
\text { Power (KVA) }\end{array}$ & $\begin{array}{c}\text { Sold Energy } \\
\text { (MWh) }\end{array}$ \\
\hline 2012 & 672153 & 1934675 & 3850 \\
2013 & 713236 & 2080149 & 4033 \\
2014 & 735446 & 2184155 & 4163 \\
2015 & 806187 & 2287234 & 4091 \\
2016 & 844224 & 2421751 & 4180 \\
\hline
\end{tabular}

Source: The Statistical Agency of Bandung Municipality, 2016

Based on the data above (Pusat \& Statistik, 2016), it can be seen that over the past 5 years the number of electricity users in Bandung has always increased, indicating that Bandung is a city that has more buildings, from year to year. Over the past 5 years, the average number of electricity users has increased to 43,017 users every year, with an increase in connected power of 121,769 KVA. In other words, the addition of connected power means that buildings will increase, while Bandung's land area decreases as green open space decreases, so it needs to be escorted by the mayor's regulation. The following in table 3 .

Based on the data above (Pusat \& Statistik, 2016), we can know that the biggest electricity user in the city of Bandung in 2016 was the type of household tariff of 772,062 users. The use of electricity by households, or especially occupancy of 1,051,625 KVA, reaches $43.5 \%$ of the total electricity consumption of Bandung Municipality in 2016. This is one reason why the Bandung Municipality Government applies the green building policy to residential. The following in table 4 .
Table 3. Customers, Connected Power and PLN Sales Revenue based on Tariff Types in Bandung Municipality in 2016

\begin{tabular}{lcccc}
\hline No & TARIF TYPE & CUSTOMERS & $\begin{array}{c}\text { POWER } \\
\text { (Kva) }\end{array}$ & $\begin{array}{c}\text { POWER } \\
\text { SELL } \\
\text { (Mwh) }\end{array}$ \\
\hline $\mathbf{( 1 )}$ & $\mathbf{( 2 )}$ & $\mathbf{( 3 )}$ & $\mathbf{( 4 )}$ & $\mathbf{( 5 )}$ \\
\hline 1 & SOCIAL & 11572 & 111815 & 164 \\
2 & HOUSES & 772062 & 1051625 & 1588 \\
3 & COMMERCIAL & 54152 & 694260 & 1055 \\
4 & PUBLIC & 3632 & 68270 & 110 \\
5 & INDUSTRY & 2764 & 495605 & 1261 \\
6 & T/C/L & 22 & 175 & 2 \\
\hline & TOTAL & 844224 & 2421751 & 4180 \\
\hline
\end{tabular}

Source: The Statistical Agency of Bandung Municipality, 2016

Table 4. Data on Drinking Water Distributed by Type of Consumer in Bandung Municipality in 2016

\begin{tabular}{ccc}
\hline No. & Custommer Type & Distributed Drinking Water (m3) \\
\hline $\mathbf{( 1 )}$ & $\mathbf{( 2 )}$ & $\mathbf{( 3 )}$ \\
\hline 1 & Social & 1212760 \\
2 & Houses & 26826291 \\
3 & Government institution & 6217340 \\
4 & Business & 8171014 \\
5 & Industry & 101042 \\
\hline & Total 2016 & 42528447 \\
\hline
\end{tabular}

Source: The Statistical Agency of Bandung Municipality, 2016

Furthermore, in terms of household drinking water consumption, it is also the largest consumer in the city of Bandung in 2016, which is as much as 26,826,291 m3, or $63.1 \%$ of all drinking water consumption in Bandung Municipality which reaches 42,528,447 m3 (Pusat \& Statistik, 2016).

The Mayor of Bandung Regulation Number 1023 concerning Green Building is intended as a reference for applicants and implementing officers in fulfilling the requirements of green buildings, with the aim of realizing building management to save, maintain and use resources efficiently, (Article 2 of Bandung Mayor regulation Number 1023 Years 2016 concerning Green Building). The target is where in the next five years it is estimated that there will be more than 2.7 million square meters of buildings that have complied with the provisions in the regulation, or almost equal to 100 times the building area of satay, and in the next ten years can save more electricity from 140 thousand MWh which is equivalent to more than USD 1 million, which is half a trillion rupiah and reduces 260 tons of $\mathrm{CO} 2$ which is equivalent to planting 90 thousand adult mahogany trees.

In this case, the Bandung Municipality Government collaborated with IFC, part of the World Bank group in partnership with the Governments of Switzerland and Hungary. Under the Indonesia Green Building Program, IFC promotes energy and water efficiency in buildings 
through the implementation of green building policies. The program is also in line with the Indonesian Government's agenda to reduce the greenhouse gas effect by $29 \%$ by 2030.

Based on the Building Construction Permit application data as of $2010,90 \%$ of buildings in the city of Bandung are 1-4 store buildings, and 10\% are above 4 floors. From the $90 \%$ figure, $80 \%$ of the land is residential and $20 \%$ of it is corporate, office and industrial buildings. The following in table 5 (Pusat \& Statistik, 2016).

Table 5. Building Data in Bandung Municipality

\begin{tabular}{cc}
\hline \multicolumn{3}{c}{ (Based on Application for IMB from 2010-2016) } \\
\hline \multicolumn{3}{c}{ Building 1-4 floors } & Building above 4 floors \\
\hline \multicolumn{3}{c}{$90 \%$} & $10 \%$ \\
\hline Occupancy & Not residential \\
$80 \%$ & $20 \%$ \\
\hline
\end{tabular}

Source: The Statistical Agency of Bandung Municipality, 2017

Basically the policy is an effort or action taken to solve a problem. As according to Abidin who stated that policy is a decision made by the government or an authorized institution to solve problems or realize the desired goals of the community. However, when referring to the definition of policy according to Robert R. Dye, policy is not always a real effort from the government, even the silence of the government in dealing with a problem is already a policy. (Choose the government to do or not do something. (Abidin Z, 2012). In the public policy process is the formulation of the policy. But before all, the basic thing that needs to be learned in the process of policy formulation is how policy analysts can recognize public problems that are distinguished from private problems. According to Dunn, the formulation of the problem will greatly help policy analysts to find hidden assumptions, diagnose the distribution of public problems, map out possible goals, integrate conflicting / conflicting views, and design policy opportunities that new. Therefore, according to Dunn further, there are phases that must be carried out carefully in formulating problems, so that the final result of the policy set can at least resolve the problems at hand. These phases consist of; problem search, problem definition, problem specification (problem solving), and problem sensing/problem recognition, (Agustino L, 2016).

The process of policy formulation is the next step after identifying and formulating the problem. At this level, various alternative strategies are calculated using criteria based on the values that exist in society. The calculation of these values is very dependent on the approach used. There are approaches that use rational models, there are approaches to incremental models, group models, game theory, and so on. These approaches have different judgments in looking at the nature of public policy which in itself has an influence on the process of policy formulation. The extent to which a policy is successful in society is largely determined by the formulation of this policy. Many policies that are generally seen by experts are quite good, but are not successfully implemented in the community, so that they do not succeed in achieving the expected goals. On the contrary, there is a policy that seems to be of less quality seen from the substance, but accepted by the community because it represents their aspirations. Even though in achieving goals there are many shortcomings,(Abidin Z, 2012). In this era of regional autonomy, any program including green buildings programs with community service dimensions is required to be of high quality (Suparman N, 2017) states that public services are actually expected by the service user community in prime form and delivery in the sense that services are easy, fast, precise and safe characterized by convoluted services, well-informed, responsive, accommodating services, consistent, and there is certainty (time, cost, law) and unofficial levies are not found. that is, the application of the principle of excellent service in methods and procedures that are closely related to public policy.

Bandung Mayor Regulation Number 1023 of 2016 concerning Green Building is a strategic policy, which basically aims to save in the use of resources to address global problems, the benefits of which will be felt by all levels of society both present and future generations. In the formulation of Bandung Mayor Regulation Number 1023 of 2016 concerning Green Building, it is necessary to pay attention to a policy formulation model (Triastuti \& MRH, 2003), offer a model of the policy-making process referring to the system model developed by David Easton. This model according to Paine and Naumes is a descriptive model because it is more trying to describe what actually happens in policy making. According to Paine and Naumes, this model is structured only from the perspective of policy makers. In this case the policy makers are seen as having a role in planning and coordinating to find a problem solving that will calculate the opportunity and reach or use internal and external support, satisfy environmental demands, and specifically satisfy the desires or interests of the policy makers themselves.This model assumes that in policy making consists of open and dynamic interactions between policy makers and their environment. Interactions that occur in the form of outputs and inputs (inputs and outputs). Output produced by the organization will eventually become part of the environment and so will interact with the organization. Paine and Naumes modified this approach by applying directly to the policy-making process. According to the system model, political policy is seen as a response from a political system to these demands seen as outputs of the political system. Political systems are a set of structures for and interrelated processes that function authoritatively to allocate values for a society. The outputs of the political system are authoritative value 
ISSN 1411 - 0911 : eISSN: 2443-2660

allocations of the system and these allocations constitute political policy. In the relationship between the two, in time there will be feedback between the output produced as part of the next input. The explanation, this model provides benefits in helping organize an investigation of policy formation. In addition, this model also realizes some important aspects of the policy formulation process, such as how environmental inputs influence the substance of public policy and the political system and how public policies affect the environment and the following demands as actions, strengths or what factors only in the environment that plays an important role to encourage the emergence of demands on the political system (Amanda \& F, 2012) According to Thomas R. Dye in (Agustino $\mathrm{L}, 2016$ ) a policy cannot be tangible in a vacuum space but it becomes a policy because of its interaction with the surrounding environment. Therefore, the policy offered by this model is a policy formulation model that departs from the output of an ongoing environment or system. In this approach five important instruments are known to understand the decision making process of a policy, namely: input, process, output, feedback, and the environment itself. Input of public policy in the context of the system model is not only in the form of demands and support but also the influence of the surrounding environment which can suppress it. The following in figure 1.Policy Formulation model from Easten, Easten in (Agustino L, 2016) policy formulation model: System model; this model is a development of David Easton's system theory. Where according to him that a policy cannot be tangible in vacuum space but it becomes a policy because of its interaction with the surrounding environment. The policy offered by this model is a policy formulation model that departs from the output of an ongoing environment or system. In this approach five important instruments are known to understand the decision making process of a policy, namely: input, process, output, feedback, and the environment itself. Input of public policy in the context of the system model is not only in the form of demands and support but also the influence of the surrounding environment which can suppress it.

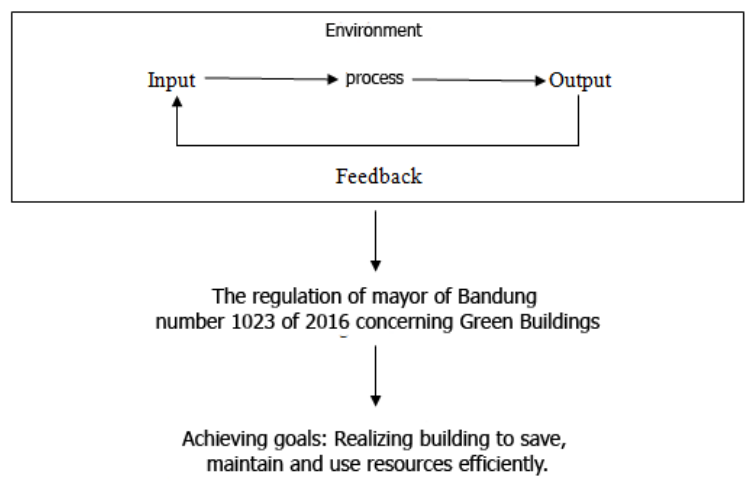

Source: Research Results, 2018.

Figure 1. Framework
Green Building, According to Article 1 Paragraph 7 of the Mayor of Bandung Regulation No. 1023 of 2016 concerning Green Buildings, green buildings are buildings that are responsible for the environment and efficient resources from the planning, implementation of construction, utilization, maintenance, to deconstruction (P. Bandung, 2016) to Article 1 Paragraph 2 of the Minister of Public Works and Public Housing Regulation No. 2 of 2015 concerning Green Buildings, green buildings are buildings that meet the building requirements and have a significant measurable performance in saving energy, water, and other resources through the appli-cation of green building principles in accordance with their functions and classifications in each stage of implementation (Kementerian PUPR, 2015). Green buildings in the city of Bandung are organized based on the following principles: (1). Does not overload the environment carrying capacity. The environment here consists of water, air and soil (2). Prioritizing the efficient use of natural resources for the purpose of building construction.

Referring to the two juridical definitions above, we can understand that green building is a concept which states that a building must pay attention to the future, by paying attention to the effective use of energy and resources and so on, in other words green building is an environmentally friendly building or environmentally friendly building.

\section{METHOD}

The qualitative research method used in this study is based on reasoning where the writer as a research instrument uses the five senses that he has and writes the results of his research into a research paper on the formulation of Bandung Mayor Regulation Number 1023 of 2016 concerning Green Building. While the descriptive design was chosen because the authors describe the theory of policy formulation with actual facts (Engkus E, 2017) related to Bandung Mayor Regulation Number 1023 of 2016 concerning Green Building. Data collection techniques used in the form of observation techniques, interviews and documentation studies (Rachmawati T, 2017). Observation techniques are used to ascertain the true state of the field. Interview techniques were used to obtain in-depth data from informants, research informants consisting of 8 people consisting of the Legal Section of the Regional Secretariat, the Head of Spatial Planning and staff, the head of the Cibiru sub-district, public policy observers, and the general public. The documentation study technique was used to obtain documents relating to green building policies, as well as to implement the realization of national development at the executive level (Engkus \& E, 2017) .Data analysis techniques using the theory of Miles and Huberman, namely data reduction, data presentation and conclusion drawing. 


\section{RESULT AND DISCUSSION}

The munipacility of Bandung is the first city in Indonesia to implement a green building policy after in 2015 the Ministry of Public Works and Housing issued Ministerial Regulation No. 2 of 2015 concerning Green Buildings. The green building policy in the city of Bandung is based on the Mayor Regulation Number 1023 of 2016 concerning Green Building. The policy formulation of the Mayor's regulation as previously explained that the regulations of the regional head, in this case the mayor's regulations are operational, sectoral, and more as an embodiment of vertical regulations from above or top down design.(P. Bandung, 2016). In its formulation is internal, which sometimes does not involve stakeholders externally both politically and with the community. So that the authors choose a suitable theory, namely David Easton which was introduced by Paine and Naumes in which this model is a development of the system theory put forward by David Easton. According to Paine and Naumes, this system model is a descriptive model because it tries to describe what actually happens in policy making. This model only consists of the perspective of policy makers. In this case policy makers are seen as having a role in planning and coordinating to find solutions to problems that will, calculate opportunities to achieve or use internal and external support; meet environmental demands; and specifically satisfy the desires or interests of policy makers themselves, (Winarno, 2016).

According to Easton, there are 5 factors or dimensions contained in a system and then this by Paine and Naumes is applied in policy formulation, namely input, process, output, feedback, and the environment in which the system is located (Agustino L, 2016). (a) Inputs, Paine and Naumes describe models of policy formation as interactions that occur between the environment and policy makers in a dynamic process. According to the system model, public policy is seen as a response from the political system to demands arising from the environment which are conditions or conditions that are outside the boundaries of the political system, where the input received is in the form of requests and support.. Claims arise when individuals or groups outside the political system play a role in influencing public policy (Febrianto, 2018). These groups actively try to influence public policy. Whereas support can be in the form of financial resources owned by the political system, and political support from individuals or groups or by the way they receive the results of elections, comply with laws, pay taxes and generally comply with policy decisions. The input which is the background for the formulation of green building policy in the city of Bandung is a global condition that is starting to be considered in terms of efficiency in the use of electricity, clean water and other energy. The United Nations Development Program (UNDP) which is an extension of the United Nations formulates the conditions of the city. Various countries in the world began to apply the concept of buildings that pay attention to energy efficiency, which is called green building. In a green building there are many parameters that must be applied in a building. With the implementation of regional autonomy, this policy began to be followed by various districts / cities throughout Indonesia. Next Mr. Irfan Febrianto as Urban Building and Architecture Staff said:

"The formula for green building is what is wanted from Mr. Ridwan Kamil (RK) and also the UNDP program, green building, he is one of the sustainable development programs. So in fact all cities in the world are again running together in this way, only by depends on what they are like and what their characteristics are " (Febrianto, 2018).

The Bandung City Government is assisted by the IFC, which is an institution under the auspices of the United Nations as the implementer of the Green Building Program from UNDP, as expressed by senior informants: Yes, IFC is part of the United Nations, so the green building has left the corridor to become e-shop, now I forget to remember, your wallet. Just browsing, there must be a UNDP program that has dozens of programs, right, program number 24, a building built in a sustainable building, there is green fermentation, green is when it comes to green building, so what number is there, there are many others. Right, IFC is an institution that helps what ... invites, right, now we help, because the City Government doesn't have a budget, there are people who have a budget and don't always want to worry, I said at the outset is good intentions, those intentions good is the leader, yesterday RK because he is an architect that he understands, he needs it. Try if, for example, who is who does it, don't you think about green building, do you think about other matters more, for example,(Febrianto, 2018). (b) Process, The process is the transition stage from the beginning in the form of input / input in the form of demands and the support becomes policy decisions. The process of formulating the Mayor's Regulation of Bandung Number 1023 of 2016 concerning Green Building is a legal procedure that begins with the submission of a draft by the relevant agencies where in this case the Office of Spatial Planning to the Mayor of Bandung through the Regional Secretariat passes through to the Legal Section, which is then formulated policy, as expressed by Mrs. Veti Rutmawan as General Functional staff, Legal Section of the Regional Secretariat of the Municipality of Bandung:

..after that .. has already entered the letter here we are the new process, the legal part of the process. By official, 
regional apparatus. For example the green building. Spatial Planning Office, right Official. His letter to the Mayor through regional secretary was copied in the Legal Department. Later it will be processed in the Legal Department, (Rutmawan, 2018)

Meanwhile, the Bandung Municipality Spatial Planning Office as the main actor in this policy, passed various processes to establish the Bandung Mayor's Regulation Number 1023 of 2016 concerning Green Building, which can be explained in the picture below.

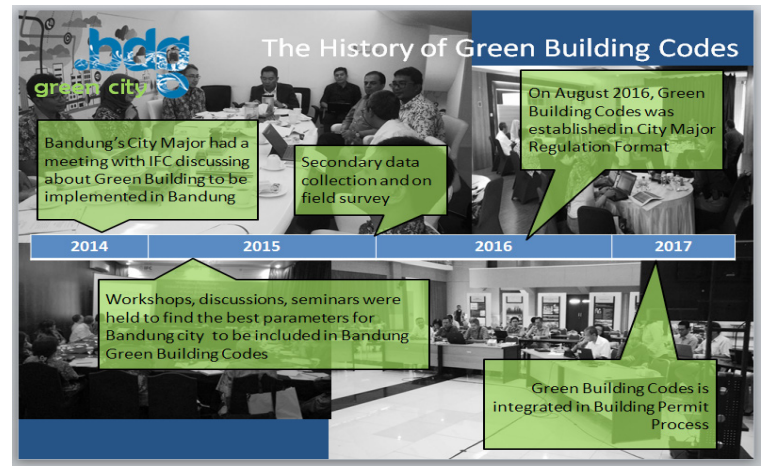

Source: The Municipality of Bandung Spatial Planning Office, 2018

Figure 2. Chronology of Bandung Green Building Policy

The Regulations of the Mayor of Bandung regarding Green Building are formulated for approximately 2 years. Where began in mid-2014, the Mayor of Bandung, Ridwan Kamil held a meeting with IFC to later became input into policy formulation.(D. T. R. K. Bandung, 2017) As explained earlier, each country has its own parameters of implementing green building in accordance with the country's conditions. Where in Indonesia, which is sheltered by the GBCI sets 5 types of greenship with 6 categories. At the end of 2015, data collection and field surveys were conducted to get an accurate picture of the current conditions. Finally, in August 2016, the Bandung Mayor Regulation Number 1023 of 2016 was established on Green Building.

(c) Output, output is the result of a process that changes demands into policy outcomes/policy outputs, a system must be able to regulate conflict or conflict resolutions and enforce these resolutions on the parties concerned. Because a system is built on the elements that support the system and this depends on the interaction between various subsystems, a system will protect itself through three things, one of which is to produce outputs that are reasonably satisfying, (Winarno, 2016). But in this policy these resolutions were not carried out against the intended conflict or conflict, but rather the solution to global environmental problems. Bandung Mayor Regulation Number 1023 of 2016 concerning Green Building is the result of ongoing processes (policy outputs), which are formulated based on the characteristics discuss the concept of green building that will be applied in the city of Bandung. Furthermore, at the beginning of 2015, various workshops, discussions and seminars were held to find the best green building parameters in accordance with the real conditions of Bandung Municipality, which of Bandung Municipality itself, which consists of 10 chapters, 85 articles and 12 attachments. The following in figure 3.

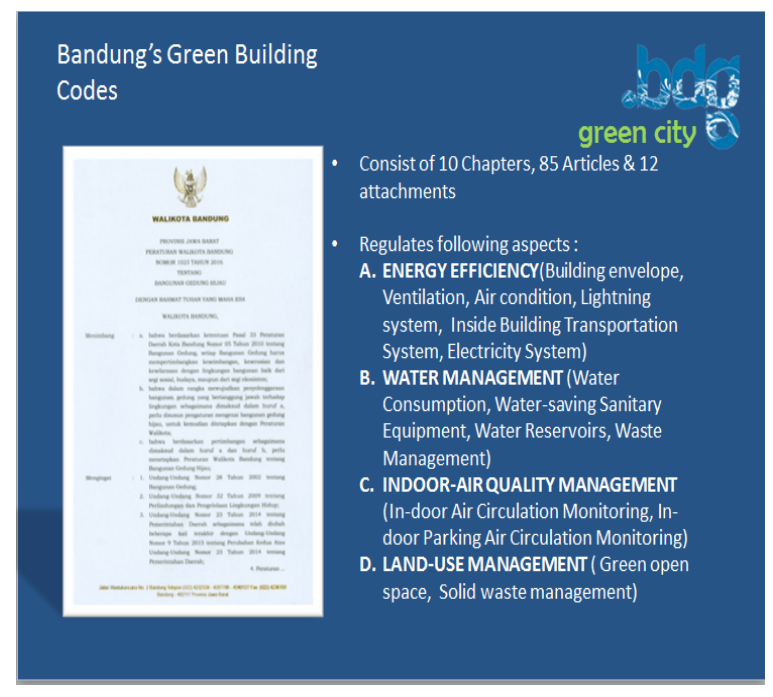

Source: The Municipality of Bandung Spatial Planning Office, 2018

Figure 3. The aspects of the Bandung Green Building Policy

But from the many aspects contained in the green building principle formulated by the World Green Building Council, not all were adopted by the Bandung Mucipality Government, only 4 aspects were included in the principle of implementing green building policies in Bandung, namely:(1) Energy efficiency, which includes layers of buildings, ventilation, air conditioning, lighting systems, transportation systems in buildings, and electrical systems. (2) Water management, which consists of water use, water saving sanitation equipment, water reservation and waste management.(3) Setting the air quality of the room, which includes monitoring room air circulation and monitoring the surface of air circulation, and (4) Arrangement of land use, which consists of green open space and solid waste management, (Processed Author, 2018) (d) Feedback, in a system is a continuation of the output or output produced. In the context of policy formulation, feedback can be seen how the policies set are the basis or the basis for other policies, the shortness of output from this system becomes input for other systems.In its implementation, the Mayor of Bandung Regulation Number 1023 of 2016 concerning Green Building will at least be the basis for policies that are planned to be formulated by the Bandung Municipality Government, which include:

(1) Building Data Collection Program, namely data collection on existing buildings for the future to be used as a database of green building, as expressed by Mr. Irfan Febrianto; 
"Well, if that was the case in 2017, then I was already, we are already in the second year, how do I learn the language, how do we make green building really implemented in the field. In 2017, the nature of socialization was yesterday, we are the ones who are important people know first, now we are starting to look for the results like what. Be the first one through building data activities, we know what data on the field are like" (Febrianto, 2018)

(2) Partner Program (Field Project); collaboration with construction associations and others, which are intended to monitor buildings that are to be erected to meet the principles of green building, so that in the future the building will be used as an example of green buildings in the city of Bandung. The second one, through what is called partner, a failed project, the filed project who was looking for developers who we think is capable of being trusted can build it according to the plan, so that later on it will be a failed project, the project is clear evidence Yeah, if asked about the example, for example, there are developers who you see, for example, the building, like this, the standard is what we use, yes, 2 of them. (3) Policies that govern Planner's Licensing Work, which are intended so that building developers have professional responsibility in applying the principles of green building. Now the third will be released at the end of the year the mayor of Bandung regulations, the name of the regulation regarding the Work Planner License, the same as in Jakarta the Planner Work Permit. So all this time the licensing process is asking for a Certificate of Work Expertise, for next year we will apply a Work Planner License, so people who have a Certificate of Work Expertise must have a Work Planner License that functions like a Driving License, if for example that is, so ... that's the fact that it's not just an architect planner, so there is construction there is a Main Contractor and there are supervisors, basically from the planning stage, construction and even later the Main Contractor has supervision to Mechanical Engineering, but at the initial stage wants to launch; planning first; the architect first because it will relate to professional associations. We have talked to the association to plan the launch of the Work Planner License, which then if the construction entrepreneur wants to have a project in Bandung must have a Work Planner License, that is the mechanism that the association must recommend for obtaining a permit (System 2019, 2019) The association will then send the name of the construction company and we will be selecting, which is unique is one of the requirements in the extension of permits that construction entrepreneurs must submit project reports for three years carrying out projects in the city of Bandung.(Febrianto, 2018).

(4) Policy on Building Function Worthy Certificate to control all buildings including buildings that have already been established so as to begin applying the principles of green building. Fourth, the last through green building Eligibility Certificate. the steps are data collection; pilot project selection (the building does not yet exist), the possibility of existing residential buildings. This was done because the licensing began in 2017.(D. T. R. K. Bandung, 2018). The focus of the work on large buildings, but the stages of recommendations and others have not been completed. In general, understanding licensing means building a building based on the concept of green building which is a new building rule in the city of Bandung. The city government of Bandung controls all buildings, both public and residential buildings, which must be based on the concept of green building, which will be given a certificate of eligibility with a format that is appropriated. The point is that Building Permit is a control tool, not Regional Original Revenue, not for local income. So inviting the public to make a permit to build a building is essentially the application of rules for broader purposes (Febrianto, 2018).

(5) Collaboration with the GBCI by recruiting it into the membership of the Building Building Expert Team. Fifth point, So the point is that in Bandung the biggest energy user is his home. The use of this energy is the result of the Green Building Council Indonesia count done by the Building Construction Team, through a Standard Operating Procedure, so that when we ask for certificates to the Intellectual Property Rights, proper certificates and building permits and reports for the last three years must be present. Thus all institutions understand and lock in the concept of green buildings in the city of Bandung.(Febrianto, 2018). (e). Environment, Within the policy environment there are two known parts, namely the Internal environment and the external environment. Where both of these environments influence public policy. This is in agreement with Anderson in (Agustino L, 2016). which states that policy formulation in practice will involve a variety of actors, both those from state and non-state actors, as official policy-makers and non-governmental participants (non-governmental participants). The influence of the external environment on the agency is influenced institutionally both vertically and horizontally in the bureaucracy(Engkus E, 2017).Thus the green building policy besides the city of Bandung which acts as an implementor, also externally, the business world and the general public. 


\section{CONCLUSION}

The policy formulation of Bandung Mayor Regulation Number 1023 of 2016 concerning Green Building is a manifestation of the sectoral and top down public ministerial regulation on public works. Although it produces policy products in accordance with the characteristics of the City of Bandung itself and has responded to global conditions, but at the design level the policy formulation is still not optimal. The contribution of stakeholders, from people who do not understand it, as well as institutional both related and territorial, this is due to the limited involvement in policy formulation. The complexity of the problem cannot yet be formulated into green building policies. So that the regulations of the mayor in order to be implemented should be improved to be a regional regulation.

\section{REFERENCES}

Abidin Z, S. (2012). Kebijakan Publik. Jakarta: Salemba Humanika.

Achdiat, \& M, Y. (2017). Model Kebijakan Peningkatan Laporan Kematian Dalam Administrasi Kependudukan dan Catatan Sipil di Kabupaten Bandung Barat. Sosiohumaniora, 19, (2), 140-148.

Agustino L. (2016). Dasar-Dasar Kebijakan Publik. Bandung: Alfabeta.

Amanda, \& F. (2012). Analisis Formulasi Kebijakan Pemberlakuan Helm SNI (Standar Nasional Indonesia) Secara Wajib bagi Pengendara Motor. Universitas Indonesia.

Bandung, D.T.R.K. (2017). Data Pembangunan Kota Bandung. B.

Bandung, D.T.R.K. (2018). Kebijakan Bangunan Hijau Kota Bandung. Bandung.

Bandung, P. Peraturan Walikota Bandung Nomor 1023 Tahun 2016 tentang Bangunan Gedung Hijau. , Pub. L. No. Nomor 1023 (2016).

Banuwa, \& I.S, E. (2018). Strategi Implementsi Kebijakan Hutan Tanaman Rakyat di KPH Gedong Wani. Sosiohumaniora, 20, (1), 29-38.

David, E. (1981). The Political System Besieged by the State. JSTOR, 9, (3), 303-325. Retrieved from http://www.jstor.org/page/info/about/policies/ terms.jsp

Engkus E. (2017). Administrasi Publik dalam Perspektif Ekologi. JISPO: Jurnal Ilmu Sosial Dan Ilmu Politik, 7, (1), 91-101.
Engkus, (2017). Implementasi Undang-undang Perdagangan: Implikasinya Dalam Kebijakan Pengadialan Harga Kebutuhan Pokok Masyarakat. Litigasi, 18, (1), 1-144.

Febrianto, I. (2018). Personal Interview. Bandung.

Kementerian PUPR. Peraturan Menteri Pekerjaan Umum dan Perumahan Rakyat Nomor 2 Tahun 2015 tentang Bangunan Gedung Hijau. Pub. L. No. Peraturan Menteri Pekerjaan Umum dan Perumahan Rakyat Nomor 2 Tahun 2015 tentang Bangunan Gedung Hijau. (2015).

Pusat Badan Statistik. (2016). Kota Bandung Dalam Angka. Bandung.

Rachmawati T. (2017). Metode Pengumpulan Data dalam Penelitian Kualitatif. In S. Ulbert (Ed.), UNPAR Press. Bandung.

Recognition. (2018). Green Buiding Council Indonesia.

Rutmawan, V. (2018). Personal Interview. Bandung.

Subijono, E. (2016). Perancangan Bangunan Hijau. Retrieved September 20, 2018, from https://pii. or.id/perancangan-bangunan-hijau

Suparman N. (2017). Kualitas Pelayanan Izin Mendirikan Bangunan (IMB) Pada Badan Pelayanan Perizinan Terpadu Dan Penanaman Modal Kabupaten Cianjur. Jurnal Borneo Administrator. Jurnal Borneo Administrator, 13, (1), 41-56.

Suyatna, U. (2019). Kebijakan Ekspor di Indonesia. Sosiohumaniora, 21, (2), 173-183.

System 2019. (2019). Rating Tools. Greenship. Retrieved January 17,2019, from http://tificatiogbcindonesia. org/greenship/cern

Triastuti, M.R.H. (2003). Analisis Formulasi Kebijakan Kenaikan Tarif Listrik, Telepon dan BBM di Tahun 2003: Disintegrate System Model of Public Policy Toward Organizational Learning and Policy Change. Center For Policy and Management Studies Bandung Parahyangan Catholic University, 2 (1), 71-86.

Wilmoth. (2011). Water and Other Resources, Especially in Urban Areas. Retrieved from https://www. google.com/h?q=Wilmoth+in+Scientific + Americ an+Magazine + on + October $+27 \% 2 \mathrm{C}+2011 \&$ aqs $=$ chrome..69i57.3269j0j8\&sourceid $=$ chrome\&ie $=$ UTF-8

Winarno, B. (2016). Kebijakan Publik; Teori, Proses dan Studi Kasus. Yogyakarta: CAPS. 